\title{
Islamic Economics: An Agenda for Intellectual and Institutional Reform
}

\author{
Mabid Ali Mohamed Mahmoud Al-Jarhi \\ Professor of Economics and Finance, \\ Ankara Social Sciences University, Turkey
}

\begin{abstract}
This article agrees with Reardon (2019), that economics finds itself in a predicament caused by the neoclassical school. The dominance of neoclassical economics and its lack of response to calls for reform has been endemic. Reform must include both the neoclassical analysis as well as the system of market capitalism it strives to defend. This paper briefly discusses both aspects of reform. It introduces the new school of analytical Islamic economics and its agenda to reform both the discipline and the economic system. The paper enumerates several advantages of Islamic economics to the economics discipline itself as well as the economy, in addition to bringing together intellectuals and scholars of economics, both from East and West, in a more communicative and inclusive group. In addition, the article makes some proposals towards opening the doors in-between the different schools of thought for positive as well as enriching intellectual interactions.
\end{abstract}

Keywords: Islamic economics, Neoclassical economics, Economic reform, Price searching models, Competitive search, Redistribution, Monetary policy, Financial markets.

JEL Classification: A2, B59, P41, Y8

KAUJIE Classification: G0, G6, G63, H1, H21, H22 


\section{Introduction}

I thank the journal for arranging this discussion forum with Jack Reardon. Without meeting face-toface, we both share objections to neoclassical economics. During the late sixties, when I was an economics student in the USA, and being a Muslim, I had always wondered about the slight attention given by market capitalism to equity. The answers to my questions could not mostly be found with my young colleagues who were proponents of radical economics. They addressed few of my apprehensions, but were limited to Western economic thinking.

As an undergraduate student in Cairo University, I did believe that economics was of practical relevance to humans. I even dreamed of how a policymaker could be so innovative to solve economic problems. By the time I was midway in my course work, I realized that regardless of the value of its intellectual exercise, it was far removed from our life. As I approached my qualifying exams, even the intellectual exercise had lost its attraction. I realized that the role of economics has been negated by neoclassical economics. As long as the economy was perpetually in a stable equilibrium, the only job for an economist was to fend off external shocks. As I was one of the first people to read Axel Leijonhufvud's (1968) book, I realized that the orthodoxy counterrevolution has won the battle, and the Keynesian revolution has been vanquished. Reading Sraffa (1926, 1960), Robertson, Sraffa, and Shove (1930), Goodwin (1990), Minsky (1977), Robinson (1972), Galbraith (1975), and several others, provided some hints regarding the counterrevolution. While I realized at the time that studying economics has taken my intellect to an impossible world of convexity and linearity, I became unsure that I wanted to belong to a tribe whose totem is the Marshallian scissors.

My attention was then directed to Islamic economics, which, at the time, was crystalized as questions without answers. In particular, it did not square up with rational thinking that the public creates a medium of exchange that the received doctrine provides no rationale for holding, while it has been held by everyone. Nor it made sense that banks take it in deposits from the public and lend to others at a premium, while the public as its creator gains nothing in return. Dissatisfaction with the neoclassical orthodoxy and market capitalism, inspired the proper questions to be asked regarding reform of both theory and system. I then decided to roll out my sleeves and work on finding answers.

I thought several times about diving into the neoclassical theory, trying to reconstruct at least some of it, outside the perfect model. However, the job appeared to be too much for one individual. In addition, those neoclassic apologists who unintentionally exposed serious weaknesses of the neoclassical paradigm, like Sonnenschein (1972), Mantel (1976), Debreu (1974), and Stigler (1957), have provided extra motivation. Steve Keen's (2011) most comprehensive critique of the neoclassical inadequacies provided a good focus.

After approaching a reasonably complete structure for an Islamic economic system, through successive articles and then a textbook in analytical economics: an Islamic perspective, which is due to be completed this summer, I can now with much confidence stand for the intellectual and practical use of Islamic economics, which I consider to be a reformist intellectual school within the discipline. It is important to note that despite its religious origin, Islamic economics is not just for Muslims, but for all humanity. Such universal message borrows its universality from Islam itself, which shares many of its basic values with Judaism and Christianity. The fall of the orthodoxy both theoretically and practically can easily be remedied by the success of the new strands of analysis. Of course, we are aware that Islamic economics can be another tribe, in Reardon's words $(2019$, p. 62$)$. However, it will be connected to other intellectual strands or tribes in more than one way. First, the desire to reform both the theory and the system. Second, its devotion to the scientific method of research that we all inherited from Ibn Rushd (Najjar, 1996).

\section{Is There A Need for Reform of Economics?}

Two types of reform are badly needed. Reforming the neoclassical paradigm as well as the reform of market capitalism. Neoclassical economics has serious conceptual problems. To list some examples, we start with its methodology. It mandates extreme rationality, utilitarianism, extreme reductionism, 
instrumentalism, equilibrium, stability, ignoring time, debt and money (for definitions of these terms, refer to Keen, 2011), and deals with equity and the environment without due attention.

As to equity, the widening gap between the rich and the poor does not attract the attention of mainstream economics, thanks to the dominance of market capitalism. Major economies in the world have failed to institute a mechanism that wipes out unemployment and empowers the weaker groups: the poor, the homeless, women, the young and the old. In the background of economic injustice, we find Western democracies which have transferred their ideal of "government by the people for the people" to "government by interest groups for interest groups", who are the most powerful elite.

The neoclassical vision does not live in the real world. It lives in a world of perfect information, extreme rationality, rational expectations, zero transactions, transport and contracting costs, and similar features found only in paradise. This is a world where equilibrium and market clearing are perpetual; stability is assured; regulation and policy remain irrelevant. Time plays no role, money is missing, debt is unimaginable. The economic system that is most akin to this theory is market capitalism, whose history has demonstrated that equilibrium is a myth, stability is rare, and equity is absent. Between the Great Depression of 1929 and the Great Recession of 2008 many downturns have beleaguered the market economy. Such crises have presented the obvious empirical proof that neoclassical economics is an aberration.

Fred Lee (2009), referred to by Reardon (2019), has discovered the research agenda to ideologically promote capitalism. This may, in part, explain how ideology was able to manifest itself through the neoclassical school. The essence of Leon Walras' (1874/ 1954) general equilibrium, containing centralized exchange chaired by an auctioneer, is a unique type of forced equilibrium, through prohibiting false trading, or trading at non-equilibrium prices. The concept of optimality itself that is based on Pareto design, reflects an extreme view of the results of the neoclassical fanciful perfect world as a materialistic economic nirvana. As Mornati $(2013$, p. 76) correctly reports that the concept of optimality (Pareto, 1902) was specifically presented to defend Laissez Faire. How ideology was able to infiltrate economics, under the cloak of marginalist misguided mathematics, and remained dominant despite several attempts for a revolution is unique among sciences.

Islamic economics started out of religious belief fourteen centuries ago, as a continuation and further development of the teachings of previous Prophets, especially, Moses and Jesus. It has recently revived itself as a reflection of Muslim religious deprivation. As Islam preaches three systems: social, economic, and political, none has had a chance to be seriously applied for centuries. Mimicking the Western culture, as expected from the vanquished to emulate the victor, has gradually infiltrated the social system. Sometimes western democracy but more often totalitarianism attempted to replace the shūrá system. The shürá system which is based on the right of the citizens to choose members of the three branches of government from amongst those qualified to properly perform government functions, has been replaced by diluted Western democracy. The Islamic economic system, based on a finance system that avoids debt and pure risk trading, in addition to a large and effective grant sector based on zakāh and $a w q \bar{a} f$, was effectively replaced by market capitalism.

The reform mission of the economic system is multifaceted. First, the current practices of Islamic finance which seriously deviate from the genuine paradigm is to be corrected. Islamic finance's underlying principles are shared by the three great religions. However, using ruses to overstep the prohibition of debt and pure risk trading has infected Muslim practitioners in the same manner that happened to our Jewish and Christian predecessors. While sharing the underlying principles, the three religions also share the ways to camouflage actions to appear falsely pious. In addition, the grant sector no longer performs significant functions due to the marginalization of zakāh and $a w q \bar{a} f$. As a result, the gap between the rich and the poor is horrifically widening, coupled with a dearth of public services. Therefore, internal reform of the contemporary applications of Islamic economics is necessary.

The second aspect of its reform mission is to move from a discipline based on figh and historical analysis, to a discipline that is based on economic analysis, making use of Ibn Rushd's (Averroes) 
scientific approach to research (al-Rsa'i, 2018; Ibn Rushd, 2001). This has been both a new trend as well as a challenging task. Islamic economists have been weaned into neoclassical economics that is replete with dogma and analytical faux pas. It is difficult to change an old habit. However, many research works have attempted to draw a new research agenda in this regard. Some of the advances in this direction include "An economic theory of Islamic finance regulation" (al-Jarhi, 2016), "An economic theory of Islamic finance" (al-Jarhi, 2017a), and "Inefficiencies in search models: The case for Islamic finance" (alJarhi, 2017b).

Such analysis points to a clearly charted venue to an economy with distinctively different features from market capitalism. First, poverty is dealt with by transferring yearly amounts of productive assets to the poor to make them productive. Second, the grant sector opens the door for people to establish public endowments or $a w q \bar{a} f$ to provide public services, especially in the field of education and health care. This reduces the tax burden on the poor and provides independence to educators. Third, its monetary and financial system envisages that the whole monetary base be placed as investment accounts with (Islamic) banks, giving the economy a boost in growth and development.

Universal banking would be the rule where banks carry out financing through profit sharing and sale finance, without lending at interest. All monetary and financial instruments are equity-based. Monetary policy would be anchored to real growth. The wealth redistribution currently effected in favor of bankers against the public through fractional reserves would be halted by the implementation of total reserves. The financial market would be devoid of debt and pure risk trading, with no finance available to financial assets trading, leading to highly subdued speculations. Such features and many more would bring about the economic reforms for which we all look forward. We can therefore say that Islamic economics has a well-defined plan for economic reform that can be applied worldwide.

In addition, the reform of mainstream economics should have some priority. The seven sins of neoclassical economics: extreme rationality, utilitarianism, extreme reductionism, instrumentalism, equilibrium, stability, and last but not least, ignoring time, debt, and money, need to be seriously addressed. Mainstream economics has to move to a new framework of disequilibrium analysis, based on search behavior. This is a challenge that must be taken by all nonneoclassical proponents. Rebuilding consumers' and firms' behavior, open models, monetary and financial economics, public finance and international trade and finance within a disequilibrium framework appears to be daunting. Nonetheless, the job must be done. Perhaps a special research agenda for this purpose should be designed with an allocation of work among interested economists. I propose that the agenda should be oriented initially towards producing textbooks that present the new reconstructed economics. The author is working on a textbook on Islamic analytical economics (al-Jarhi, 2019) that reconstructs some parts of mainstream economics, while referring the remaining parts to others.

The issue of economics being dominated by one school of thought with questionable methodology and an analysis that is faulty in many aspects is rather serious. Especially that policymakers belong to a school which claims that market capitalism is selfregulating, crises do not exist, and policy could be a source of distortion. Policymakers with such intellectual orientation would not be successful in facing crises. They would also turn a blind eye towards the increasing gap between the rich and the poor, as they believe that income distribution is meritocratic.

Confronting such a dominant school for the purpose of reforming the discipline requires joint efforts from other schools of thought. A new, perhaps globally implemented research agenda should be drawn, with some allocation of labor among nonneoclassical economists to do the following:

- Write plans for textbook material that present real alternatives to neoclassical economics.

- Lobby with institutions of high education to teach courses containing alternative approaches to neoclassical economics, including Islamic economics, and the critique of the neoclassical received doctrine.

- Lobby with journals, which are mostly edited by neoclassical economists, to open their doors for publishing contributions of economists belonging to other schools of thought. 
- Make textbooks and research material written by non-neoclassical economists freely available on the internet.

- Design online courses and degrees on alternative approaches to economics.

\section{Islamic Economics Is an Answer}

As explained above, Islamic economics - shaped in the way I have advocated - provides a sound reform plan for both the intellectual work and the economic system. Despite the fact that it has been inspired by religion, which provides the main values and behavioral rules, it would not be dogmatic. As long as we have adopted the analytical approach with a scientific methodology that avoids the neoclassical extreme assumptions, everything would be subject to deduction and induction.

An example is the prohibition of the rate of interest. Islamic economists would endeavor to show that an interest-based monetary and financial system would be inefficient and open to instability as well as contagion. Obviously, some pious Muslims would hesitate to use this approach, as they prefer to obey the divine rules without questioning. However, putting the divine rules to test would be the only way to provide policy justifications. To assure this group, the analytical approach has so far succeeded in providing rationale for Islamic economic teachings, so that we do not need to worry about the conflict between science and reason. This is a point that Ibn Rushd tried to argue, causing a clash between him and Muslim (al-Ghazali) and Christian (Thomas Aquinas) theologians who feared that their creed would not stand to reason.

We present Islamic economics as an answer, while keeping the door open for other intellectual efforts to challenge and/or provide alternative answers. As long as we are human, we must accept our fallibility. In Islamic economics, we interpret the divine teachings into concepts, paradigms, and systemic rules. However, our interpretation is fallible and remains subject to dialogue with other schools. This way, Islamic economists can be considered pluralistic in the sense that we are open for dialogue and collaboration with other economists.

\section{Has Economics Transformed?}

I must agree with Jack Reardon (2019) in answering this question. I join him in emphasizing that neither the doctrine nor the system has changed. As long as education and policymaking are controlled by the incumbents, we do not expect reform to be considered, let alone taken seriously.

\section{How Useful Have Been the Reforms?}

Here again, I add my voice to Reardon's, emphasizing that whatever steps have been taken under the guise of reform have not been serious or effective. Reform taking place outside neoclassical economics has been more serious and promising. We all have a duty to encourage non-neoclassical schools of thought to multiply their efforts to provide alternative material, reflecting a new methodology that is both realistic and defensible.

\section{The Role of Ethics and Morals}

Reardon has saved me the effort to show that neoclassical economics does not bother with treating ethics explicitly. In addition, the implicit ethics of the orthodoxy are disappointing. The utility and profit maximizing agent is a dangerous example to follow. Taken to its extreme, people should have no compassion for each other, should not take care of their children or the poor, and the government should provide only the minimum of public services, like health and education. In addition, an individual would be a winner if he consumed the maximum possible amount and died in debt.

Islamic economics meanwhile, starts with man as a vicegerent of Allah. As such, man has economic rights that start before his birth. Such rights cover the provision of basic needs and merit wants. Economic actions must be measured by the maqāssid al-Sharī ah (the objectives of Sharī'ah) in economics, which include, balanced and sustainable growth, employment, equity, and stability. Usurping public wealth, harming the environment, and indulging in wasteful consumption, are all contrary to the objectives of Sharīah. Since Islamic economics is inspired by the divine teachings, it automatically adopts the Islamic moral values. This cannot be escaped. 
Moral values must be ingrained in the economic system to be reflected in production, consumption, investment, and trading. The prohibition of interest has its economic rationale, based on efficiency. It also has its moral rationale of being unjust to the borrower. Zakāh, as a redistributive system is not a privilege of the poor, but it is their entitlement. Therefore, the economic system must contain the institutional and policy arrangements that guarantee the implementation of Islamic moral values.

\section{Is History of Economic Thought Still Relevant?}

Reardon has expressed my mind on this, giving valid reasons to accept the relevance of the history of economic thought. Tracing the evolution of our theories over time provides our theoreticians an invaluable guidance to move forward with their analysis. It also gives our policymakers the right clue of whether they have fulfilled their mission in serving their societies or not.

\section{What Implications Does Contemporary Reform Have for Islamic Economics?}

Reardon has provided several aspects in which Islamic economics can influence the reform of both the economic doctrine and the economic system. I have also attempted above to explain how Islamic economics in itself can provide a reform program both intellectually for our economic theories and practically for our economic system. To be more specific, Islamic economics starts with building a new economics, based on a new methodology. The unit of analysis becomes the homo ordinarius, who is an ordinary human being, with bounded rationality, who suffices but never maximizes. This is not a simplifying assumption, but an attempt to bring our theory down to realism. Such a person maps his preferences over a limited number of commodities and his search is concerned with a limited number of options. This all is a big break from the highly calculative rational homo economicus whose preferences are defined over the entire commodity set and whose options cannot be compared even with multiple super computers.

The price searching behavior follows the model of competitive search, through which the homo ordinarius keeps searching for the prices of his limited options until no more reduction in prices can be achieved. Meanwhile the price-searching firm posts prices but stands willing to listen to customers and haggle, which results in extra services, discounts, sales, and the like. The results, as we explain in our textbook (al-Jarhi, 2019) is a floating disequilibrium, where neither market demand nor market supply can be aggregated from individual demand and supply schedules. This summarizes our new approach to Islamic economics that is intended to overhaul microeconomics in no simple fashion.

Islamic macroeconomics, meanwhile, is based on the proper application of Islamic finance, with no ruses whatsoever. A monetary authority that issues and allocates monetary balances based on investment and not lending criteria. The central bank invests its monetary-base through universal banks that provide finance using several finance and investment modes. The financial market deals with only equity-based instruments (shares, $s u k \bar{u} k$, fund certificates, investment certificates) in addition to a new money-market instrument, that is the Central Bank Investment Certificate or CD's. The proceeds of the latter instrument are added to the central bank investment accounts with banks. Open-market operations in CD's are used to fine tune the changes in the money supply. Large changes can be made through direct additions to central bank investment accounts.

The rate of return on CD's is market determined; unlike the rate of interest, which is an administered price. It has a stable relationship with the real rate of growth, which makes it an ideal anchor for monetary policy. In such an environment, full employment and price stability are within reach. In addition, zakāh regularly transfers productive assets to the poor, for the purpose of raising their productivity and enlarging their role in economic development. Moreover, $a w q \bar{a} f$ provide free education and health services to the poor in particular. Overall, the structure of an Islamic economic system has unprecedentedly effective tools to reach the economic goals of full employment, stability, balanced growth, and equity.

There are several interesting things about our newly suggested structure that avoids the neoclassical assumption of perfect competition. First, economists no longer have to look for inconsistencies to end up with embarrassingly impossible solutions, as in the case of the Sonnenschein-Mantel-Debreu condition. Second, the complete removal of the rate of interest from the financial structure (unlike Friedman's zerobound interest rate proposal) eliminates the 
Friedman-Samuelson inefficiency that results from attempts to substitute real resources for money in transactions (al-Jarhi, 2017b). Third, the switch to universal banking allows price searchers to internalize the information in price searching activities, bringing the volume of trading closer to optimal and removing the Hosios inefficiency (al-Jarhi, 2017b). Fourth, the elimination of debt and pure risk trading as well as the financing of short-term speculations (Ponzi Scheme) in financial markets improves the transmission mechanism and raises the levels of speed of adjustments. In other words, the market mechanism itself is liable to improve when our proposals for systemic reforms are implemented. Fifth, the implementation of zakāh and awqāf pays out in faster and more effective economic development, not to mention the gains in social cohesion and stability. Many more benefits can be counted. However, the most important aspect of the Islamic economic agenda is to become true to intellectual rationality à la Ibn Rushd, without insisting on the extreme rationality of our unit of analysis.

The most important gain from our agenda is the adoption of an analytical approach to Islamic economics. In this way, we break the barriers between the school of Islamic economics and other schools of thought within the discipline as we can bring our methodologies closer together. We can then learn from each other. As the Middle-Ages West has previously benefited from Muslim intellectuals to build their renaissance, the contemporary West can equally benefit from the cross-fertilization of ideas with Islamic economics.

\section{Conclusions}

First, the received doctrine of neoclassical economics suffers from several drawbacks in methodology and analysis. Attempts to find solutions out of its analytical bottlenecks returned embarrassing results indicating that neoclassical economics can hardly be saved.

Second, the neoclassical orthodoxy that is currently dominant closed its eyes to necessary reforms of the discipline. In addition, the contemporary economic system of market capitalism has not taken seriously the potential of reform, despite repeated crises.

Third, Islamic analytical economics, provides a credible agenda for reforming both the orthodoxy as well as the system of market capitalism. However, intellectual barriers between Western and Islamic economist must be opened to make such agenda available all over the world. Contributions made at a wider geographic and ideological scale would be more substantive as well as effective.

Fourth, pluralism must be taken as both a school of thought and a value that is common among all contemporary economics schools of thought. We must not only compare notes and cross fertilize ideas, but consider that the discipline of economics needs the efforts of all of us to be able to move ahead.

Fifth, non-neoclassical schools of thought must cooperate in developing new teaching materials and opening the doors to joint theoretical and empirical research to present credible alternatives to neoclassical economics. 


\section{References}

Debreu, G. (1974). Excess demand functions. Journal of Mathematical Economics, 1(1), 15-21.

Galbraith, J. K. (1975). Economics and the public purpose. New York, USA: New American Library.

Goodwin, R. M. (1990). Chaotic Economic Dynamics. Oxford, UK: Oxford University Press.

Ibn Rushd. (2001). Faith and Reason in Islam: Averroes' Exposition of Religious Arguments (I. Najjar, Trans.). Oxford, UK: Oneworld.

al-Jarhi, M. A. (2016). An Economic Theory of Islamic Finance Regulation. Islamic Economic Studies, 24(2), 1-44.

al-Jarhi, M. A. (2017a). An Economic Theory of Islamic Finance. ISRA International Journal of Islamic Finance, 9(2), 117-132.

al-Jarhi, M. A. (2017b). Inefficiencies in Search Models: The Case for Islamic Finance (MPRA Working Paper No. 82064). Retrieved from: https://mpra.ub.unimuenchen.de/82064/1/MPRA_paper_82064.pdf

al-Jarhi, M. A. (2019). Economic Analysis: An Islamic Perspective. Ankara Turkey: Ankara Social Bilimler Üniversitesi and Participation Banks Association of Turkey [TKBB] (forthcoming).

Keen, S. (2011). Debunking Economics: The Naked Emperor Dethroned. London, UK: Zed Books.

Lee, F. (2009). A History of Heterodox Economics: Challenging the Mainstream in the Twentieth Century. London, UK: Routledge.

Leijonhufvud, A. (1968). On Keynesian Economics and the Economics of Keynes: A Study in Monetary Theory. New York, USA: Oxford University Press.

Mantel, R. R. (1976). Homothetic preferences and community excess demand functions. Journal of Economic Theory, 12(2), 197-201.

Minsky, H. P. (1977). The financial instability hypothesis: an interpretation of Keynes and an alternative to "standard" theory. Nebraska Journal of Economics and Business, 16(1), 5-16.
Mornati, F. (2013). Pareto Optimality in the work of Pareto. Revue européenne des sciences sociales: European Journal of Social Sciences, 51(2), 65-82.

Najjar, I. Y. (1996). Ibn Rushd's Theory of Rationality. Alif: Journal of Comparative Poetics, 16, 191-216.

Pareto, V. (1902). Di un nuovo errore nello interpretare le teorie dell'economia matematica [On a new error in the interpretation of the theories of mathematical economics]. Giornale degli Economisti, 25(13), 401433.

Reardon, J. (2019). Dialogue on Reform in Mainstream Economics and its Implications for the Islamic Economics Discipline. Journal of King Abdulaziz University: Islamic Economics, 32(2), 61-75.

Robertson, D. H., Sraffa, P., \& Shove, G. F. (1930). Increasing Returns and the Representative Firm: A Symposium. The Economic Journal, 40(157), 79-116.

Robinson, J. (1972). The second crisis of economic theory. The American Economic Review, 62(1/2), 1-10.

al-Rsa'i, Mohammed. (2018). Knowledge Theory in Ibn Rushd Literature and reflection thereof on its Educational philosophy. International Journal of Progressive Education, 14(1), 1-7. https://files.eric.ed.gov/fulltext/EJ1170087.pdf

Sonnenschein, H. (1972). Market excess demand functions. Econometrica, 40(3), 549-563.

Sraffa, P. (1926). The laws of returns under competitive conditions. The Economic Journal, 36(144), 535-550.

Sraffa, P. (1960). The Production of Commodities by Means of Commodities: Prelude to a critique of economic theory. Cambridge, UK: Cambridge University Press.

Stigler, G. J. (1957). Perfect competition, historically contemplated. Journal of Political Economy, 65(1), 1-17.

Walras, L. (1954). Elements of pure economics OR The theory of social wealth (W Jaffe, Trans.). Illinois, USA: American Economic Association and the Royal Economic Society. (Original work published 1874) 
Mabid Ali Al-Jarhi is currently Professor of Economics and Finance at the Ankara Social Sciences University, Turkey. He graduated from Cairo University in 1960, obtained his MA degree from the University of Illinois, Graduate Resident Studies, University of California (UCLA), and completed his $\mathrm{PhD}$ in economics from the University of Southern California (USC) in 1975. Currently he is coordinating the establishment of the ASBU International Center for Islamic Economics and Finance. The establishment of the ASBU Journal of Islamic Economics is also underway. Recently, he was honored with the IDB Prize in Islamic Economics, Banking and Finance, 2019. He is also a member of the Shari' ah Board of the Dubai Financial Market (DFM). He has held many high-ranking positions in his long-standing career. He was the Director General at the Islamic Research and Training Institute (IRTI), IDB, and was the Chief Editor of its journal. He also worked as the Director at the IDB Department of Economics, Jeddah, where he participated in establishing SESTRIC, Ankara, and started a program for financing trade among Muslim countries. In the Arab Monetary Fund, he served as the Secretary General of the Council of Arab Governors of Central Banks and was the editor of the Joint Arab Economic Report, yearly presented to the Arab League. He also held the position of Financial Advisor and Head of Training for the Emirates Islamic bank, and participated in the establishment of new Islamic banks in Algeria, Bosnia, and Kazakhstan, and in changing the banking laws in Syria and Kazakhstan to allow for Islamic banking. He has taught economics at USC, Cairo University, and the Institute of National Planning, Cairo; and Islamic economics at the Khomeini Institute, Iran, Hamad Ben Khalifa University, Qatar, and INCEIF University, Malaysia. He is currently working on the first textbook in analytical Islamic Economics, to be published this year, that includes several breakthroughs in the field.

E-mail: mabid.al.jarhi@gmail.com 


\title{
الاقتصاد الإسلامي: جدول أعمال للإصلاح الفكري والمؤسسي
}

\author{
معبد على محمد محمود الجارحي \\ أستاذ الاقتصاد والتمويل، جامعة أنقرة للعلوم الاجتماعية، تركيا
}

المستخلص. يتفق هذا المقال مع ريردون (2019م) ، في أن علم الاقتصاد يجد نفساه في مأزق تسببت

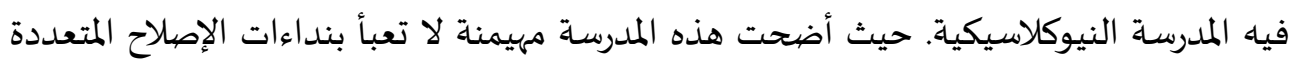

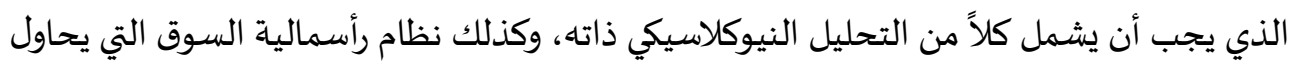

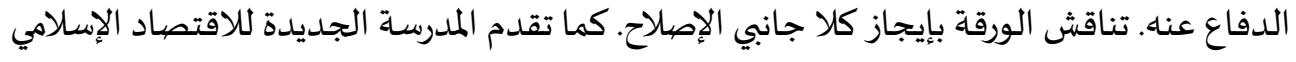

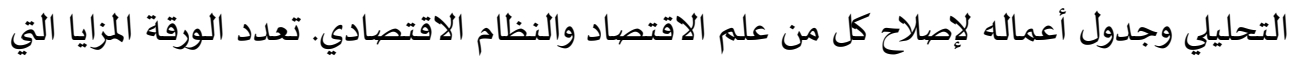

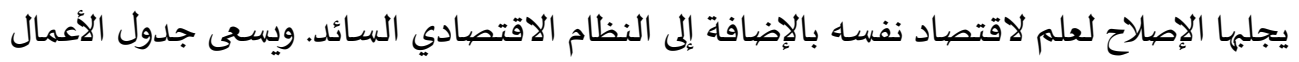

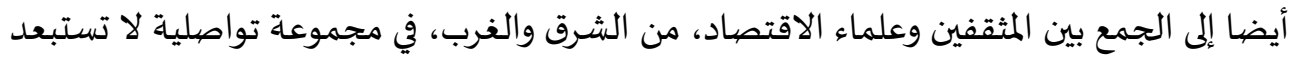

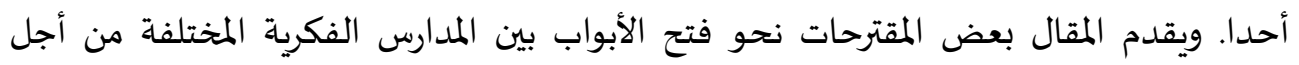
التفاعلات الفكرية الإيجابية بغرض الإثراء المعرفي.

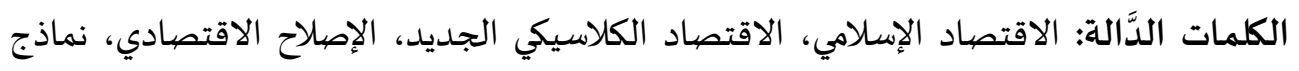
البحث عن الأسعار، البحث التنافسي، السياسة النقدية، الأسواق المالية، إعادة التوزيع.

تصنيف Y8،P41 B559 A2

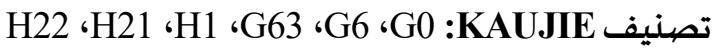

